J. TECHNICAL WRITING AND COMMUNICATION, Vol. 37(1) 3-16, 2007

\title{
THE USE OF PATHOS IN CHARITY LETTERS: SOME NOTES TOWARD A THEORY AND ANALYSIS
}

MARSHALL MYERS

Eastern Kentucky University

\begin{abstract}
Americans contribute $\$ 240$ billion dollars to charities each year, raised in part by writing letters to potential donors. While it is debatable what the reasons are for donors to give so much money, most donors seem to be moved to contribute by pathos, particularly pity. The concept of pathos as a rhetorical appeal has become more complex over the years, growing from a simple strategy to a complicated set of parameters requiring careful delineation. Beginning with the Greeks, particularly Aristotle, pathos was defined with greater clarity (especially the concept of enargia), with Aristotle's formal definitions of the emotions, and with the use of an image upon which to direct the audience's pity. Cicero adds to the theory by calling for the use of pathos in the peroration and reinforcing Aristotle's emphasis on careful audience analysis. St. Augustine and those who follow, including Renaissance, 18thcentury rhetoricians, and 20th-century scholars like Kenneth Burke, argue that style can also be an effective persuasive strategy for a pathetic appeal. Accordingly, the charity letters examined illustrate not only Aristotle's and Cicero's tenets but also show that elements of style, particularly rhetorical figures and schemes, are common rhetorical strategies used in these charity letters. While at first the rhetoric of charity letters seems simple and straightforward, to raise billions of dollars every year charity letters use sophisticated appeals to pity that have a long and interesting history.
\end{abstract}

Americans are a generous people. In fact, Charles Clark, writing in Congressional Quarterly Researeher, notes that the "American tradition of philanthropy" is "unique in all the world" [1]. Along that line, using data from the American Association of Fund Raising Counsel, Robert Franklin of the Minneapolis Star 
Tribune, concludes that Americans give away at least $\$ 240$ billion to charities each year, distributing that money to the nearly 800,000 charities listed by the Internal Revenue Service [2].

Besides telephone solicitations, one of the most popular ways of collecting that enormous amount of cash is through charity letters. In fact, according to the United States Postal Service, 14 to 15 billion pieces of mail, about $7 \%$ of the total volume of mail, seek donations to a variety of charities in the United States [2]. One woman in Minnesota, for example, over a year collected 1430 letters from various charities that included pleas for money to support heart, cancer, and various religious organizations, just to name a few [2].

Why do people give to charities?

While that is perhaps a knotty, age-old question, tied to the various notions of the nature of human beings as a species, recent research by Ernst Fehr and Suzann-Viola Renniger, published in Scientific American Mind, indicates that popular notions about why human beings help each other seem to be incorrect. As these two researcher say, "Recent experiments show that current gene-based evolutionary theories cannot adequately explain important patterns of human altruism" [3, p. 15]. Older theories saw human beings as philanthropists less out of an "expression of love of humankind than out of the cool calculation of the entrepreneur who seeks to ensure future profit by clever public relations," something on the order of "you scratch my back and I'll scratch yours" [3, p. 17]. And some sociobiologists in the past have suggested that altruistic acts performed "for the benefit of others are really motivated by veiled economic calculations and selfishness or by egoism with an eye to the very long term" [3, p. 15]. Antonio R. Damasio in Descartes' Error: Emotion, Reason, and the Human Brain notes, for example, that "In addition to the obvious good that altruists bring to others, they may heap good upon themselves in the form of self-esteem, social recognition, public honor, and affection, prestige, and perhaps even money" [4, p. 176]. Yet Fehr and Renniger dispute those notions. To them, "the strong altruist is one who does good out of motives other than mere nepotism or strategic gain" [3, p. 19]. After a series of intricate scientific experiments that would allow for choices between selfish and selfless behavior, Fehr and Renniger found that "our species is apparently the only one with a genetic makeup that promotes selflessness and true altruistic behavior" [3, p. 21]. Damasio even admits that "Some sublime human achievements come from rejection of what biology or culture propels individuals to do" [4, p. 177]. While it is probably unwise to generalize about the nature of all of humankind's actions based on a limited number of scientific experiments, Fehr and Renniger do offer at least one interesting insight, which, along with older less optimistic theories of altruism, may help to explain why Americans, whether for selfish or altruistic reasons, contribute such large amounts of money to charities each year.

So if billions of letters are sent to prospective donors each year, and if Americans in response contribute billions of dollars to charities, those facts spawn 
an interesting set of two related questions: In writing such letters, what techniques do charities use to get donors to contribute such large amounts of money? Or, to put it still another way, what is the rhetoric of such letters?

The simple answer to these questions is that these letters appeal to our emotions, particularly to the emotion of pity. Donors contribute money, so the reasoning goes, because they feel sorry for the people this money is supposed to help, an appeal to the readers by what the ancient Greeks called pathos. But the concept of pathos in general and pity in particular as pathetic appeals are complex subjects that can best be understood by tracing their history and development, which, in turn, provides a foundation for a theory of how charity letters use pathos. In sum, our understanding of pathetic appeals begins with the ancient Greeks, particularly Aristotle, whose painstaking analysis of various emotions, including pity, strongly hinted at the need for an image upon which to project an emotion. Following that, the Roman rhetorician Cicero added to our understamding by reinforcing Aristotle's emphasis on audience analysis and by calling for a strongly emotional peroration. St. Augustine then enriched the concept by injecting Christianity into a pathetic appeal and by his and subsequent generations' emphasis on including style as a persuasive device.

First, definitions are in order. One source, The Encyclopedia of Rhetoric and Composition, defines pathos as "an argumentative/persuasive appeal to the emotions of the audience" [5, p. 492]. As one of the three basic appeals (ethos, pathos, and logos), pathos "is based upon the rhetor's ability to arouse certain types of emotions in the audience" [5, p. 493]. Another source, The Encyclopedia of Rhetoric, defines pathos in Greek rhetoric as a state which is "allied with the Greek verb paskhein, to undergo, experience, suffer, or more generally, to be in a state or condition, and the Greek noun pathos preserves this range of meaning" [6, p. 555].

Sharon Crowley and Debra Hawhee in their book Ancient Rhetorics for Contemporary Students, go farther, carefully pointing out that "Emotions should be distinguished from appetites, such as pleasure and pain" [7, p. 205]. Damasio, for example, calls these appetites "primary emotions" and concludes that "... the mechanism of primary emotions does not describe the full range of emotional behaviors. ..." Demasio continues, "I believe that in terms of an individual's development they are followed by mechanisms of secondary emotions, which occur once we begin experiencing feelings and forming systematic connections between categories of objects and situations, on one hand, and primary emotions on the other" (italics in the original) [4, p. 134]. Crawley and Hawhee seem to agree, suggesting these primary emotions "must also be distinguished from values, such as justice and goodness," and add that "people do hold values with more or less intensity, and this intensity is where the rhetorical force of emotional appeals resides" [7, pp. 205-206], for pathos is a very potent persuasive strategy.

In Classical Rhetoric for the Modern Student, Edward P. J. Corbett and Robert Connors make another important point about pathetic appeals, warning that 
pathos, in the minds of many people, doesn't have a very good name. Corbett and Connors say: "People are rather sheepish about acknowledging that their opinions can be affected by their emotions. They have the uneasy feeling that there is something undignified ... about being stirred into action through the stimulus of . . aroused passions" [8, p. 77]. Crowley and Hawhee agree, adding that "Of all the ancient kinds of rhetorical proofs, the appeal to the emotions seems the strangest to contemporary rhetors, and perhaps a little bit shoddy as well. That's because of the modern reverence for reason and our habit of making a sharp distinction between reason and emotion" [7, p. 206].

But Corbett and Connors are also careful to note that "There is nothing necessarily reprehensible about being moved to action through emotion; in fact, it is perfectly normal. Since it is our will ultimately that moves us to action and since the emotions have a powerful influence on the will, many of our actions are prompted by the stimulus of our emotions" [8, p. 77]. In other words, many times it is an emotional appeal that pushes people into action. It would be difficult, indeed, for example, to imagine a social cause so great and so appealing to the masses that did not in some way have an emotional element in it. The Revolutionary War, the Civil War, and the Civil Rights Movement in the 1960s, to name just three, all certainly had their persuasive logical arguments, but the leaders in large part used pathetic appeals to motivate their audiences.

As noted earlier, pathos, to be sure, is a concept that has changed over time, nuanced by the age, by the circumstances, and by the rhetorical scholar. As The Encyclopedia of Rhetoric is quick to point out, "For some rhetors, the term [pathos] conveys little more than the sense that the auditor's state of mind can cloud or supersede his rational capacities for making decisions. For others, the term invites a thorough analysis of the human soul and its broader relations to language and perception" [6, p. 555]. In the end, a richer understanding of pathos as a concept requires a discussion of how the concept evolved over time.

The concept of rhetorical pathos, an appeal nearly 2500 years old, was employed by, among others in 5th-century Greece, the early Greek rhetorician Gorgias [6, p. 556]. Many scholars say that Gorgias argued effectively on Helen of Troy's behalf and absolved her from blame for the Trojan War because she was persuaded by a powerful pathetic appeal. In "Encomium of Helen," Gorgias says that Helen took her course of action because she was persuaded by emotion. As Gorgias says: "For speech constrained the soul, persuading it which is persuaded, both to believe the things said and to approve the things done.". . "or if it was love which did all these things, there will be no difficulty in escaping the charge of the sin which is alleged to have taken place" [9, p. 41]. Helen is exonerated, Gorgias argues, because she was persuaded to take her course of action by passion. In Gorgias's mind, the passion of love "has the divine power of the gods, how could a lesser being reject and refuse it?" [9, p. 42]. Yet while Gorgias acknowledges the power of a pathetic appeal, he does not really analyze emotion as an appeal, other than to recognize that it exists and that it is potent. 
The idea of pathos grows into the complex appeal it is today beginning with the classical Greek philosophers. Plato, for example, seems, at times, to have little use for an emotional appeal of any kind - particularly in the dialogue Gorgias, ironically where he condemns the use of rhetoric in almost any form. Later, though, in several places, including Phaedrus, Plato discusses the use of emotion in speech, observing that "the task before rhetoricians is to gain better knowledge of the kinds of souls and the kinds of emotions which appeal to those souls through speech" [6, p. 557]. But Plato's advice is cautious. As Michael J. Hyde says: "By setting up an opposition between emotion and reason whereby emotion is conceived as an irrational impulse destructive of a person's thoughtful judgment, Plato could discredit both the mythopoetic and rhetorical uses of discourse because of their intentional and solitary appeal to this impulse" [10, p. 122]. But as a careful study of Plato's dialogues makes clear, any systematic discussion of pathos would have to wait on a richer understanding of this appeal and its uses.

That wait, fortunately, was not long, for Aristotle, Plato's student, discusses the pathetic appeal at some length in his Rhetoric, particularly in Book 2. Aristotle begins by defining emotions as "all those feelings that so change men as to affect their judgements, and that are also attended by pain or pleasure. Such are anger, pity, fear and the like, with their opposites" [11, p. 92]. Aristotle thus delineates what Hyde calls "a more positive conception of emotion and its relationship to rhetorical and poetic discourse than allowed by Plato" [11, p. 122]. As Hyde notes, "For Aristotle, then, the emotional character of human beings plays an important role in their development; it constitutes a person's spirited potential for coming to know what is true, just, and virtuous" [10, p. 123]. In Rhetoric, then, Aristotle sets about to define and to discuss the various 16 emotions used by rhetors and to advise rhetors on how to generate each in speech.

For purposes of this discussion particularly, Aristotle defines pity as "a feeling of pain caused by the sight of some evil, destructive or painful, which befalls one who does not deserve it, and which we might expect to befall ourselves or some friend of ours, and moreover to befall us soon" [11, p. 113]. We feel pity for those who are the victims of "destructive evils" like "death in its various forms, bodily injuries and afflictions, old age, diseases, lack of food, ... the evils due to chance" among them "friendlessness, scarcity of friends and companions, deformity, weakness, mutilation, evil coming from a source from which good ought to have come, and the frequent repetition of such misfortunes" [11, p. 114]. Aristotle adds that "Here too we have to remember the general principle that what we fear for ourselves excites our pity when it happens to others. Further, it is when the sufferings of others are close to us that they excite our pity" [11, pp. 114-115). But, Aristotle says, the "most piteous of all is it when, in such times of trial, the victims are persons of noble character" [11, p. 115].

Then, Aristotle particularly gives advice on how to excite pity in the audience. He suggests, for example, that those who engender the most pity in the audience 
are those who "put the disasters before our eyes, and make them seem close to us, just coming or just past" [11, p. 115]. This particularly effective technique is called enargia, which A Handlist of Rhetorical Terms defines as "a generic term for visually powerful, vivid description which recreates something or someone as several theorists say "before your very eyes"” [12, p. 64]. A Handlist of Rhetorical Terms uses phrases to define the concept such as "person-to-person immediacy - the impact we feel, perhaps, in live television at its best" [12, p. 64].

Although Aristotle does not say it directly, the implication is strong that in order for pathos to be effective and to create enargia, there must be somethingin this case - to pity, something - in other words - to embody the emotion. Otherwise, the emotion floats in the mind of the audience with seemingly no place to light. As The Encyclopedia of Rhetoric says, "Images are particularly effective in arousing emotions, whether those images are visual or direct as sensations, or cognitive and indirect as memory or imagination, and part of a rhetor's task is to associate the subject with such images" [6, p. 555]. And if those images are especially vivid, they are much more likely to persuade the readers and move them to an appropriate action. As Crowley and Hawhee conclude, "it is easier to make people afraid and angry toward a person than it is to make them afraid and angry toward an abstraction" [7, p. 211].

The charity letters for this study, a large shoe box full collected by the author over three months, display these persuasive images in abundance. In fact, almost every letter contained an image as part of its pathetic appeal. For example, a letter from an organization working with children begins with a stark image upon which to cast the reader's pity:

Eight months into her pregnancy, Lauri [X.] learned that her child would have spina bifida, a serious birth defect. "I didn't know what to do."

The reader is drawn then to pity a particular object; this time it is a person, Lauri. That image, then, provides a place for our pity to light.

A second letter illustrates how writers can project pity itself not just onto a person, but also to an object; this time, appropriately, to a wheelchair:

If I could say one thing from personal experience . . . a wheelchair is a lonely place if you think no one cares. ...

Here, while the image is a wheelchair, a non-human object employed by people who are usually the object of pity by many people, all the associations of pity and the victim coalesce around that wheelchair for a very powerful pathetic effect.

The writer for another charity, asking for donations around Christmas time, uses not only images upon which to cast the reader's pity, but employs very vivid description that illustrates enargia at work:

I'm thinking of a young mother with her 3-year-old daughter who appeared at the door of [the name of the charity] one rainy night. Neither of them had shoes on, and mud caked their feet and legs. The mother's husband had 
locked them out of their home. They were frightened and desperate for help, but had no friends or family to turn to. They hadn't eaten all day . . . and they didn't have any place to sleep.

Here the images include a rain-soaked, "frightened" and "desperate" mother and child who are locked out of their house one dark night by the husband and father. The images are numerous, striking, and quite pathetic in appeal, and they help build the concept of pity in the reader's mind by giving the reader specific and vibrant objects to pity.

But the ancient Greeks were not the only rhetoricians to try to understand pathos as a concept. In fact, the Romans, particularly Cicero, added significantly to our understanding of the idea by specifically reinforcing the importance Aristotle placed on analyzing the audience in order to create pathos, and by calling for the placement of the most pathetic appeals in the peroration. According to Joseph Colavito, writing in The Encyclopedia of Rhetoric and Composition, Cicero keenly understood that "the importance of analyzing the audience and its susceptibility to emotional appeals plays a significant role in the [Cicero's rhetorical] theory" [5, p. 493]. In Cicero's On Oratory and Orators, he stresses how important audience analysis is to oratory, for the rhetor "must penetrate the inmost recesses of the mind of every class, age, and rank, and must ascertain the sentiments and notions of those before whom he is pleading" [13, p. 67]. In another place, Cicero again stresses audience analysis, saying the orator must know "what their sentiments and opinions are, what they expect, to which side they incline, and to what conclusion they are likely to be led, with least difficulty, by the force of oratory" [13, p. 134]. But Cicero sees the rhetor's "highest power," however, to be "exciting the minds of men ..." [13, p. 19]. The source of this strong emphasis on the passions traces back to what The Encyclopedia of Rheroric calls the "Roman taste for theatrical displays of all sorts" [5, p. 560]. Accordingly, Cicero reasons, the best place in the rhetorical artifact for this conscious display of emotion is in the ending of the speech. Cicero, for example, notes that "you must not spring at once into the pathetic portion of your speech, as it forms no part of the question, and men are first desirous to learn the very point to come under the judgment ..." [13, p. 143]. As Colavito says, "The emotional appeal, according to Cicero, is of significant influence in the construction of the speech's peroration..." [5, p. 493].

We can see Cicero's ideas at work in several examples taken from charity letters. In one letter, the peroration pleads with the reader to donate to a charity that supports medical research into heart disease by addressing the reader by name:

Dr. Myers, please don't give up the fight against America's No. 1 killer. We have not heard from you in some time and your support is missed. It does make a difference. Won't you please send \$15 or more today and help us save more lives in Richmond? Think of it as an investment in your own future and in the futures of those you love. 
Placed at the end of the letter and addressed to the reader by name, the peroration has a great deal of force, especially since a question is directed at a specific reader and especially since the letter ends in the emotion-packed phrases "in your own future and in the futures of those you love."

Another letter illustrates how the writer has not only ended on a pathetic note, but who also has tied the same image that began the letter with the image that closes the letter, while at the same time underlining key phrases and noting that the reader's donation will not just help one child:

So please sign your Christmas card and return it with your caring gift today. Your card will give hope and encouragement to a St. Jude patient like Madelyn and her family. And your donation will help ensure that every child at St. Jude continues receiving excellent care, and help us advance our groundbreaking cancer research. Your gift could be the one that tips the scale in favor of Madalyn ... saving her life, and perhaps the lives of thousands more children fighting cancer.

Another letter ends in a particularly piteous way, calling up the image of Joyce, a homeless girl, mentioned in the opening of the letter, and illustrating the tradition of using extreme emotions that Cicero and his fellow Romans were so fond of through the use of phrases like "say a prayer," "lives in fear of relapse," "I will say a special prayer for you and your loved ones":

And tonight, if you can do me one more favor, please say a prayer for Joyce. It hasn't been easy for her, and she still lives in fear of a relapse every day. While I'm praying for Joyce tonight, I will say a special prayer for you and your loved ones. The covenant you and I have made with these kids is the best thing — in many cases the only thing — in their lives.

Besides the Greeks and Romans, others have added to our understanding of the concept of pathos. Although he did not invent the concept, in On Christian Doctrine, St. Augustine, writing some 500 years later, emphasized something quite significant about pathos, stressing that the orator must "speak sweetly" [14, p. 136], emphasizing that what you say and how you say something are both part of the pathetic appeal. Of the low, middle, and grand styles, St. Augustine saw the grand style as particularly suited for moving the will, what The Encyclopedia of Rhetoric calls using "all linguistic sources" [6, p. 562]. Thus, employing the powerful stylistic device of repeating similar syntactic structures himself, St. Augustine suggests that the listener is convinced if the rhetor realizes that the audience is:

persuaded if he loves what you promise, fears what you threaten, hates what you condemn, embraces what you commend, sorrows at what you maintain to be sorrowful; rejoices when you announce something delightful; takes pity on those whom you place before him in speaking as being pitiful, flees those whom you, moving fear, warn are to be avoided; and is moved by whatever else may be done through grand eloquence toward moving the 
minds of listeners, not that they may do what they already know what is to be done, but that they may do what they already know should be done" [14, pp. 136-137].

What St. Augustine has to say about pathetic appeal is particularly important because the Bishop of Hippo also places rhetoric squarely into a Christian context. In other words, the pathetic appeal for St. Augustine has two engines driving it: the rhetorical knowledge about pathetic appeals and their effectiveness that St. Augustine derived from his secular training in rhetoric, and the motivation to use such appeals because they are legitimated by the teachings of Christ who himself used such emotional appeals as pity, for example.

To deal with the latter first, it should not be surprising then that Christian charities make use of some of the suggestions of St. Augustine in their letters. This is not to say that these writers have all read, understood, and implemented what St. Augustine wrote, but the tradition of giving to charities because of pity is deeply seated in the basic tenets of Christianity.

One charity, for example, says that it "honors the birth of Jesus with gifts throughout the year - gifts that help children heal" (italics in the original). Later, in the same letter, the writer addresses the reader, saying "Together, we can renew those feelings of wonder and surprise and share in His [i.e., Christ's] peace by heeding His call — to love and protect all children, always" (italics in the original).

Even charities not affiliated with a church make use of this same linking of religion and pity. The Cancer Recovery Foundation of America focuses on a cancer survivor, Greg, and says that "The truth of Romans 8:28 became real in our lives as God turned Greg's adversity to good by giving him the vision of starting the Cancer Recovery Foundation in 1985." Later in the same letter, the writers affirm that they "have also shed tears over seeing God perform miracles." Still later, the letter says that "Greg is praying that God will provide supporters. ..." Near the hortatory close of the letter, one of the writers asserts that "As a wife, I pray that God will lead you to be a part in this work by sharing a gift to help change lives."

In its history, such a notion of linking Christianity with pathetic appeal appears again in the Renaissance when rhetoric is seen to be, according to The Encyclopedia of Rhetoric, "a tool given by a Christian God, the better to know God's universe and bring the soul into closer communion with God" [6, p. 563].

These rhetors of the Renaissance also reinforce St. Augustine's emphasis on style as a pathetic appeal. Fifteenth-century Dutch Humanist Roelof Huysmann, known as Rudolphus Agricola, for example, recognized that "certain kinds of language have an affinity for certain kinds of emotion, not simply in terms of meaning, but also in tone and in the shape and patterns of language treated in elocutio" [6, p. 564]. By the 1700s, the Slavic rhetorician Feofan Prokopovic even delineated "how different tropes and figures achieve effects appropriate to 
each affect" [6, p. 565]. In another age, Alexander Campbell, in The Philosophy of Rhetoric published in 1776, spent much of that treatise on the role of passion in rhetoric. Campbell saw the passions also intricately related to style, concluding that "the kind of address of which I am treating, attains the summit of perfection in the sublime (italics in the original), or those great and noble images, which, when in suitable coloring presented to the mind, do, as it were, distend the imagination with some vast conception, and quite ravage the soul" [15, p. 751]. Just a few years later, in 1783, one popular rhetorician would argue that the passions also assist in generating an appropriate style. In fact, Hugh Blair echoes Campbell, by noting that "passion rouse[s] and kindle[s] the mind, without throwing it out of possession of itself[;] [it] is universally found to exalt all the human powers. It renders the mind infinitely more enlightened, more penetrating, more vigorous, and masterly than it is in calm moments" [16, p. 971]. In Language as Symbolic Action, noted 20th-century rhetorician Kenneth Burke concludes that style is also a part of the pathetic appeal. In speaking about the effectiveness of the great Greek orator Demosthenes, Burke observes that the orator's "persuasiveness becomes more like sheer literary appeal ..." [17, p. 296]. Or as he says later, "style' becomes 'ritual,", a part of the "word magic" of a rhetorical artifact [17, p. 301]. Writing in the Journal of Business Communication in 1985, Craig Kallendorf and Carol Kallendorf argue that "our speech betrays our feelings when we are angry: connectives are passed over in asyndeton, key words are emphatically repeated in anaphora, clauses become shorter and more direct through parallelism, and so forth" [18, p. 41]. Pathos and style are, then, according to this long line of thinkers, inextricably mixed together.

Several letters illustrate how style can have a persuasive edge to it. One letter, for example, effectively uses a scheme that first begins with a negative sentence and then follows that sentence with its positive counterpart that also includes a repetition of the word threat:

We don't protect species [of animals] because they're cute or appealing. We protect them because, given the interdependence of life on this planet, a threat to any of them is a threat to us all.

Parallelism is also a common stylistic feature in the letters. For instance, one letter sets off three statements in parallel structure, underlines them to increase their power, and arranges the sentences in climactic order with the most important sentence placed last:

$\underline{\text { It takes as little as } 45 \text { minutes. }}$

It costs as little as $\$ 250$.

It changes a child's life forever.

Another letter asks the reader a rhetorical question and then follows that with three parallel adverbial clauses with the important noun phrases underlined: 
Why do I believe-as I hope you do-that significant progress can still be made?

Because we've already made great strides through the programs in place ... because we have the proven tools that have saved countless children's lives ... ... and because we've seen the extraordinary results that a committed, focused effort can produce.

The charity letters include other long passages that feature parallelism, composed of infinitive phrases, for example, which the writers accentuated by underlining phrases in bold face type to increase their persuasive power:

There is always more we all can do: to protect our basic right to dignity and choice in both living and dying, to give time and space to reach difficult decisions; to listen, really listen to patients, family, and caregivers; to keep each and every patient pain-free and functional, and hospice has the medical and nursing knowledge to do that!); and above all, to 'be there.'

Another letter employs wit rather than structure for its effect. The writers of the letter pun on the word hand:

My friend, we're not asking for a handout—just a helping hand.

Still another technique is to use an extended string of nouns that climaxes with an adjectival clause at the emphatic last position of the sentence:

It will mean that we, our loved ones and friends, can have the chance to grow old with dignity rather than with the fear, frustration, suffering, despair and ravaging decline that Alzheimer's brings.

These stylistic devices are persuasive, then, in part because they use language in a clever way, assuming tacitly, that style is a part of the persuasive power of a letter. The reader will donate, supposedly, because the letter in part is cleverly stated and thus attractive to the reader, or because the letter is spoken "sweetly," as St. Augustine would say.

What is obvious from this analysis is that when we look at the rhetorical techniques of charity letters, the writers, consciously or unconsciously, seem to be operating out of a lengthy tradition of scholarship about pathetic appeals. Consequently, understanding how charity letters effectively use pathetic appeals is predicated on understanding how the concept of pathos evolved over 2500 years of scholarship, including the thinking of Aristotle about emotions, Cicero's emphasis on audience analysis and the use of a strongly pathetic peroration, and St. Augustine and a bevy of other rhetoricians' emphasis on style as a part of the pathetic appeal.

It should be pointed out, too, though, that there is a significant use of visual rhetoric in these letters, for visual rhetoric is a consideration in the 21 st century in any analysis of the persuasive techniques used in a contemporary rhetorical artifact. These letters are no exception. They make use of such devices as 
typographical bullets, text underlining, different colors of paper and print, pictures in black and white and in color, and bold type in their total appeal. As John Lannon says in his popular textbook Technical Communication, "visuals are a staple of communication today" [19, p. 289]. Mike Markel, in Technical Communication, agrees and points out that visuals of various sorts assist in communicating difficult material, help to "clarify and emphasize information," "catch the reader's attention," "help nonnative speakers of English understand the information," and "help communicate information to multiple audiences with different interests, aptitudes, and reading habits" [20, p. 319]. But Lannon quickly notes that that "doesn't mean that verbal messages have become obsolete. Instead, words integrate with shapes and images" to produce the total message [19, p. 289]. Part of the appeal of the letters examined is also derived from the offering of address labels, membership cards, and decorative pins, since they have perhaps some persuasive weight in helping readers decide whether or not to contribute to the charity. But while these same devices are important considerations for any persuasive analysis, they are not, however, the main focus of this present discussion.

Finally, it has also not been the purpose of this analysis of charity letters to disparage them as written documents, to assert or to imply that they make pernicious use of rhetorical tricks that "fool" donors into shelling out hard-earned money for dubious purposes. Charities in the past and do now perform vital services for American society, services that provide food and housing for many well-deserving recipients. Today, politicians of multiple persuasions even support giving governmental funds to what in many instances are "faith-based initiatives" or charities.

Yet, at the same time, understanding better how charity letters work as rhetorical artifacts increases our knowledge of just how those thousands of letters that flood mailboxes all over this country ply their craft and supply money so that charities can perform the important services they do. While, at first, their rhetoric seems simple and straightforward, charity letters, taken as a whole, use sophisticated rhetorical techniques that have a long history, derived from important and influential thinkers who understand and appreciate the usefulness of pathos as an appeal worthy of careful examination and judicious use.

\section{REFERENCES}

1. Congressional Quarterly Researcher, Charitable Giving, 1993. 26 May 2005. $<$ http://www.library2.cqpress.com/cqresearcher/document.php?id=cqresrr>.

2. Lexis-Nexis, Charities Come Calling, a Lot, 2005. 26 May 2005. $<$ http://www.web.lexis.com/universe $>$.

3. E. Fehr and S. Renniger, The Samaritan Paradox, Scientific American Mind, 14:5, pp. 14-21, 2004. 
4. A. Damasio, Descartes' Error: Emotion, Reason and the Human Brain, Quill, New York, 2000.

5. J. Colavito, Pathos, Encyclopedia of Rhetoric and Composition, T. Enos (ed.), Garland, New York, pp. 492-494, 1996.

6. Pathos, in Encyclopedia of Rhetoric, T. O. Sloane (ed.), Oxford, New York, pp. 554-569, 2001.

7. S. Crowley and D. Hawhee, Ancient Rhetorics for Contemporary Students, Longman, New York, 2004.

8. E. P. J. Corbett and R. J. Connors, Classical Rhetoric for the Modern Student (4th Edition), Oxford, New York, 1999.

9. Gorgias, Encomium of Helen, in The Rhetorical Tradition, P. Bizzell and B. Herzberg (eds.), Bedford, New York, 1990.

10. M. J. Hyde, Emotion and Human Communication: A Rhetorical, Scientific, and Philosophical Picture, Communication Quarterly, 32, pp. 120-132, 1984.

11. Aristotle, Rhetoric, W. R. Roberts (Trans.), Modern Library, New York, 1954.

12. R. A. Lanham, A Handlist of Rhetorical Terms (2nd Edition), University of California Press, Berkeley, 1991.

13. Cicero, On Oratory and Orators, J. S. Watson (Trans. and Ed.), Southern Illinois University Press, Carbondale, 1970.

14. St. Augustine, On Christian Doctrine, D. W. Robertson, Jr. (Trans), Prentice Hall, Upper Saddle River, New Jersey, 1997.

15. A. Campbell, From The Philosophy of Rhetoric, in The Rhetorical Tradition, P. Bizell and B. Herzberg (eds.), Bedford, New York, 1990.

16. H. Blair, From Lectures on Rhetoric and Belle Lettres, in The Rhetorical Tradition, P. Bizell and B. Herzberg (eds.), Bedford, New York, 1990.

17. K. Burke, Language as Symbolic Action, University of California Press, Berkeley, 1966.

18. C. Kallendorf and C. Kallendorf, The Figures of Speech, Ethos, and Aristotle: Notes toward a Rhetoric of Business Communication, Journal of Business Communication, 22, pp. 35-50, 1985.

19. J. M. Lannon, Technical Communication (10th Edition), Pearson Longman, New York, 2006.

20. M. Markel, Technical Communication (7th Edition), Bedford/St. Martin's, Boston, 2004.

\section{Other Articles On Communication By This Author}

Myers, M., The Million Dollar Letter: Some Hints on How to Write One, Journal of Technical Writing and Communication, 34:2, pp. 133-143, 2003.

Myers, M., A New Look at Infinitives in Business and Technical Writing, Journal of Technical Writing and Communication, 32:4, pp. 59-65, 2002.

Myers, M., A Syntactical and Rhetorical Analysis of Selected Annual Reports, ERIC ED 440 387, 2000.

Myers, M., The Influence of the Purpose of the Business Document on its Syntax and Rhetorical Schemes, Journal of Technical Writing and Communication, 9:4, p. 408, 1999. 
Myers, M., Rhetoric Hewn by Audience and History: The Evolution of the Corporate Annual Report, ERIC ED 370 138, 1994.

Myers, M., Using the Personals to Teach Voice in Technical Writing, Bulletin of the Association of Teachers of Technical Writing, 4:2, p. 4, 1994.

Direct reprint requests to:

Marshall Myers

Dept. of English

Eastern Kentucky University

Richmond, KY 40475 
Copyright of Journal of Technical Writing \& Communication is the property of Baywood Publishing Company. Inc. and its content may not be copied or emailed to multiple sites or posted to a listserv without the copyright holder's express written permission. However, users may print, download, or email articles for individual use. 